УДК 655.3.022.11.2

\title{
ДОСЛІДЖЕННЯ ЯКОСТІ ВІДТВОРЕННЯ БЛАНКІВ МАЙНОВИХ СЕРТИФІКАТІВ
}

(๖ Я. О. Шевченко, магістр, О. В. Зоренко, к.Т.н., доцент,

В. М. Скиба, к.т.н., ст. викладач, НТУУ «КПІ», О. Ю. Байдак, к.т.н., доцент, ТОВ “Мак Хаус», Київ, Україна

\begin{abstract}
Исследовано взаимодействие основных расходных материалов и влияние их свойств на качество воспроизведения ценных бумаг типа приватизационного имущественного сертификата (ПИС). Предложены методы и средства стабилизации печати ПИс.
\end{abstract}

Research of basic supplies and their influence on the properties of printing quality securities such as privatization property certificates (PPS). Methods and means for stabilizing the printing PPS.

\section{Постановка проблеми}

Цінні папери - документи встановленої форми 3 відповідними реквізитами, що посвідчують грошові або інші майнові права, визначають взаємовідносини особи, яка ї розмістила (видала), і власника, та передбачають виконання зобов'язань згідно з умовами ї розміщення, а також можливість передачі прав, що випливають із цих документів, іншим особам.

Друкування бланків цінних паперів в Україні здійснюють поліграфічні підприємства, що мають відповідні повноваження і ліцензію Мінфіну України та оснащені спеціалізованим обладнанням і використовують закриті технології [1].

Вимоги до якості друкування цінних паперів, зокрема ПМС, значно вищі, аніж для звичайної поліграфічної продукції. Ідентичність відбитків за колірними та іншими показниками якості результат впровадження не ли- ше новітньої техніки на всіх етапах виготовлення, а й комплексу заходів підвищення технології виробництва, контролю якості відбитків і матеріалів, задіяних у технологічному процесі виробництва [1, 2].

Якість відбитків даного виду поліграфічної продукції залежить від впливу технологічних параметрів, зокрема процесу друкування, властивостей витратних матеріалів, навколишнього середовища, в якому відбувається їх взаємодія та професійного рівня виробничих працівників.

\section{Аналіз попередніх досліджень}

В Україні у цивільному обігу є такі цінні папери як пайові, боргові, іпотечні, приватизаційні, похідні, товаророзпорядчі. ПМС - це особливий вид державного цінного паперу, що засвідчує право власника на безоплатне одержання у про- 
цесі приватизації частки майна державних підприємств [3].

Технічні вимоги до виготовлення бланків цінних паперів встановлюються з урахуванням терміну обігу, номіналу, а також виду цінних паперів (іменних, ордерних або на пред'явника).

Бланки цінних паперів (за винятком чеків і акцій з купонами) повинні мати формат A4 (210×297 мм) або А5 (148×210 мм), бланки акцій з купонами - A4; A4+; A5 або A5+, чеки - формат, кратний формату A2, але не менше A6 (105×148 мм).

Для виготовлення бланків цінних паперів (у тому числі додруковування напівфабрикатів) можуть застосовуватися наступні види друку: металографічний (приховане зображення у рамках, розетках); офсетний (усі різновиди; приховане зображення у рамках, розетках), високий (друк флуоресцентними, електропровідними або магнітними фарбами серії і номера); орловський. Кожен бланк має бути віддрукований не менше ніж двома видами друку. Для іменних цінних паперів ірисовий друк переважний, а для на пред'явника і ордерних - обов'язковий.

Цінні папери повинні виготовлятися на папері масою $1 \mathrm{~m}^{2}$ 80-120 г. Чеки допускається виготовляти на папері масою $1 \mathrm{~m}^{2}$ 60-80 г.

Папір не повинен містити оптичні вибілювачі (бланкофори), тобто не повинен мати світіння (люмінесценції) під дією ультрафіолетового випромінювання. До складу паперу повинно входити бавовняне або льняне волокно в кількості, визначуваній видом і терміном дії цінного паперу.

Друковані реквізити (основні сюжетні зображення, портрети, фонова захисна сітка, серійний номер) мають бути чіткими, однакового тону. Бланк цінних паперів повинен мати не менше трьох різних за формою і малюнку гільоширних елементів, одні з яких мають позитивне, а інші негативне виконання ліній. Окрім цих елементів захисту можливе застосування кінеграм, голограм, портретів, металізованих флуоресцентних («срібних») фарб, невидимих елементів, що флуоресціюють в ІЧ-промінях [4].

Узагальнюючи вищезазначене розроблено класифікацію цінних паперів, що наведена на рис. 1.

Для отримання якісних відбитків ПМС в офсетному плоскому друці необхідно дотримуватися таких загальних технологічних умов: підбирати компоненти системи «друкарська форма-зволожувальний розчин-фарба-задруковуваний матеріал» у відповідності один до одного та технологічних умов друкування; підтримувати оптимальні кліматичні умови на складах попередньої підготовки до друку паперу і фарб, в друкарському цеху; здійснювати поетапний контроль якості згідно з нормативними вимогами. Більшість вищезазначених умов пов'язані з процесом друкування, зокрема дотриманням балансу «фарба-зволожувальний розчин», впливом на якість відбитків властивостей даних матеріалів [1, 2, 5]. 


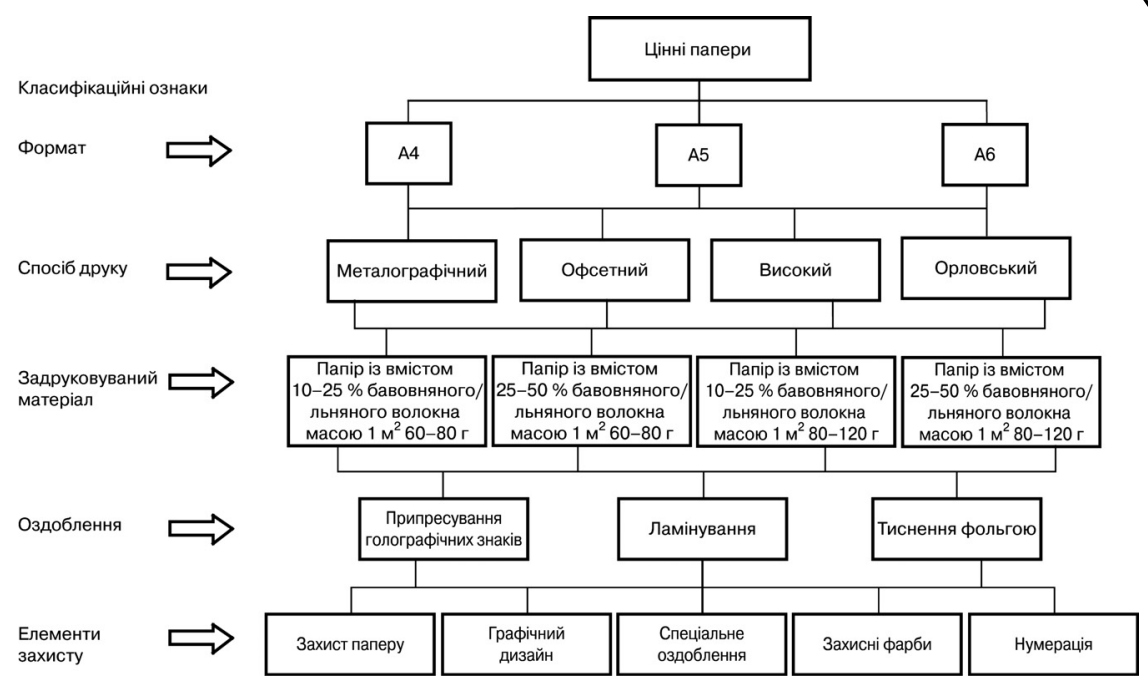

Рис. 1. Класифікація цінних паперів

Тому актуальним $€$ дослідження параметрів та методів стабілізації процесу друкування ПМС.

\section{Мета роботи}

Забезпечення оптимального технологічного процесу друкування ПМС шляхом стабілізації властивостей складників друкарського контакту та використання засобів зниження впливу шкідливих викидів на працівників та в навколишнє середовище.

\section{Результати проведених досліджень}

Дослідження якості друкування ПМС проводили на аркушевій офсетній друкарській машині Rapida 105 із застосуванням тріадних офсетних фарб K+E Novavit® 2 F 700, зволожувальних розчинів (ЗР): спиртового 3 домішкою Stabilat $\mathrm{DH}$ 2010 у кількості 1,5 \% та експериментального безспиртового 3 додаванням домішки (у кількості
2,5 \%) для коригування електропровідності, офсетного паперу «GF» LG, масою 1 м² 80 г.

Дослідження електропроводності ЗР показали, що її значення у експериментальному ЗР (1512 мкСм) більш прийнятні, ніж спиртового (1765 мкСм), оскільки знаходяться в допустимих межах (робоча електропровідність ЗР 800-1500 мкСм). Тому подальше дослідження якості відтворення ПМС за контролем одиничних показників (оптичної густини, колірних показників, передача градацій, розтискування) було з використанням вищезазначених типів 3P.

Отримані дані вимірювання зональних оптичних густин відбитків ПМС із застосуванням спиртового ЗР (рис. 2, а-г), свідчать про нестабільність друкарського процесу, що полягає в невідповідності кількісних значень показника існуючим стандартам якості. Наприклад, згідно з міжнародним стандар- 

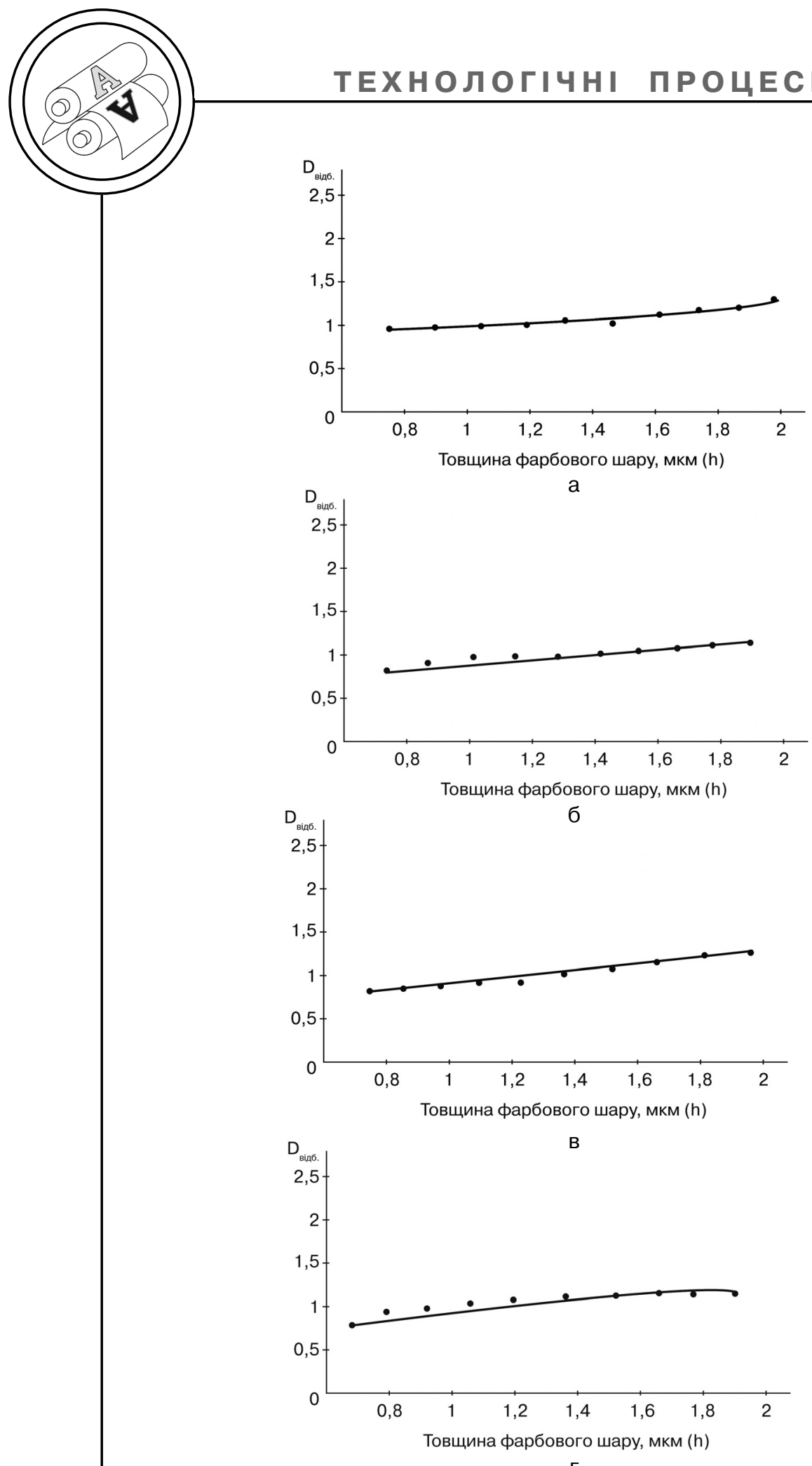

Рис. 2. Розподіл оптичної густини: а - чорна фарба; б - жовта фарба; в - пурпурна фарба; г - блакитна фарба 
том ISO 12647-2 [6] оптична густина жовтої та пурпурної фарб для офсетного паперу складає

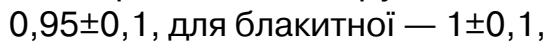

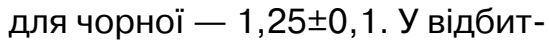
ках досліджуваних накладів ПМС оптична густина блакитної фарби змінюється від 0,84 до 1,16, пурпурної - від 0,8 до 1,15, жовтої - від 0,79 до 1,11, чорної - від 0,97 до 1,26. Отже, тільки оптична густина чорної фарби відповідає вимогам.

Для порівняльного аналізу денситометричних і колориметричних показників відбитків накладів ПМС, надрукованих з експериментальним складом ЗР і оцінки їх на відповідність існуючим стандартам [6] за допомогою спектрофотометра виміряно зональну оптичну густину тріадних фарб (рис. 3, а-в), колірні відмінності (рис. 4), розтискування в 50 \% полі (рис. 5).

Згідно з рис. 3 показники оптичної густини виміряних відбитків ПМС для тріадних фарб коливаються в межах від 1,19 до 1,28 Б, що перевищує на 0,18 одиниць допустимі значення. Колірні відмінності (рис. 4) пурпурної фарби $(2,54)$ та блакитної $(3,04)$, лежать в допустимих межах, жовтої $(5,76)$ - перевищують допустимі значення [6].

Згідно 3 [6] розтискування хроматичних фарб в 50 \% полі повинно складати $14 \% \pm 4 \%$. Розтискування досліджуваних фарб у відбитках накладів ПМС (рис. 5) знаходяться в допустимих межах: для жовтої фарби змінюється від 6 до 10 \%, пурпурної - від 10 до 15 \%, блакитної - від 12 до 13 \%.

Отже, висока якість виготовлення ПМС залежить від бага- тьох чинників. Не останнє місце належить 3Р. Емульгування фарби і порушення балансу «фарба-ЗР» викликає появу таких дефектів: нашарування фарби на офсетному полотні, оголення фарбових валиків, повільне висихання фарби на відбитку і низьку стійкість до стирання. Окрім цього надмірне подавання ЗР впливає на передачу кольорів і градацій: погіршується контраст і взаємне накладення фарб, отже, обмежується колірне охоплення, друк стає нестабільним [1, 2, 7].

Отже, нестабільність друкарського процесу може бути викликана зміною електропровідності ЗР. Використання автоматизованої системи підтримки зволоження дозволить покращити показники якості друку. Тому запропоновано встановити патентовану систему управління зволоженням Optimizer (Ecografica, Італія). Пристрій для управління зволоженням підключається до системи рециркуляції ЗР і до водопроводу. Система самостійно підготовлює розчин і автоматично підтримує його параметри. Також система дозволяє контролювати і зменшувати показник поверхневого натягу за допомогою спеціального пристрою типу «багатоступеневого паралельного магніту». Принцип його роботи в наступному: вода швидко прокачується навколо постійних магнітів, виконаних у вигляді стрижнів, при цьому на неї перпендикулярно руху діють змінні електромагнітні поля. Величини цих полів підібрані таким чином, щоб забезпечити ефект потуж- 


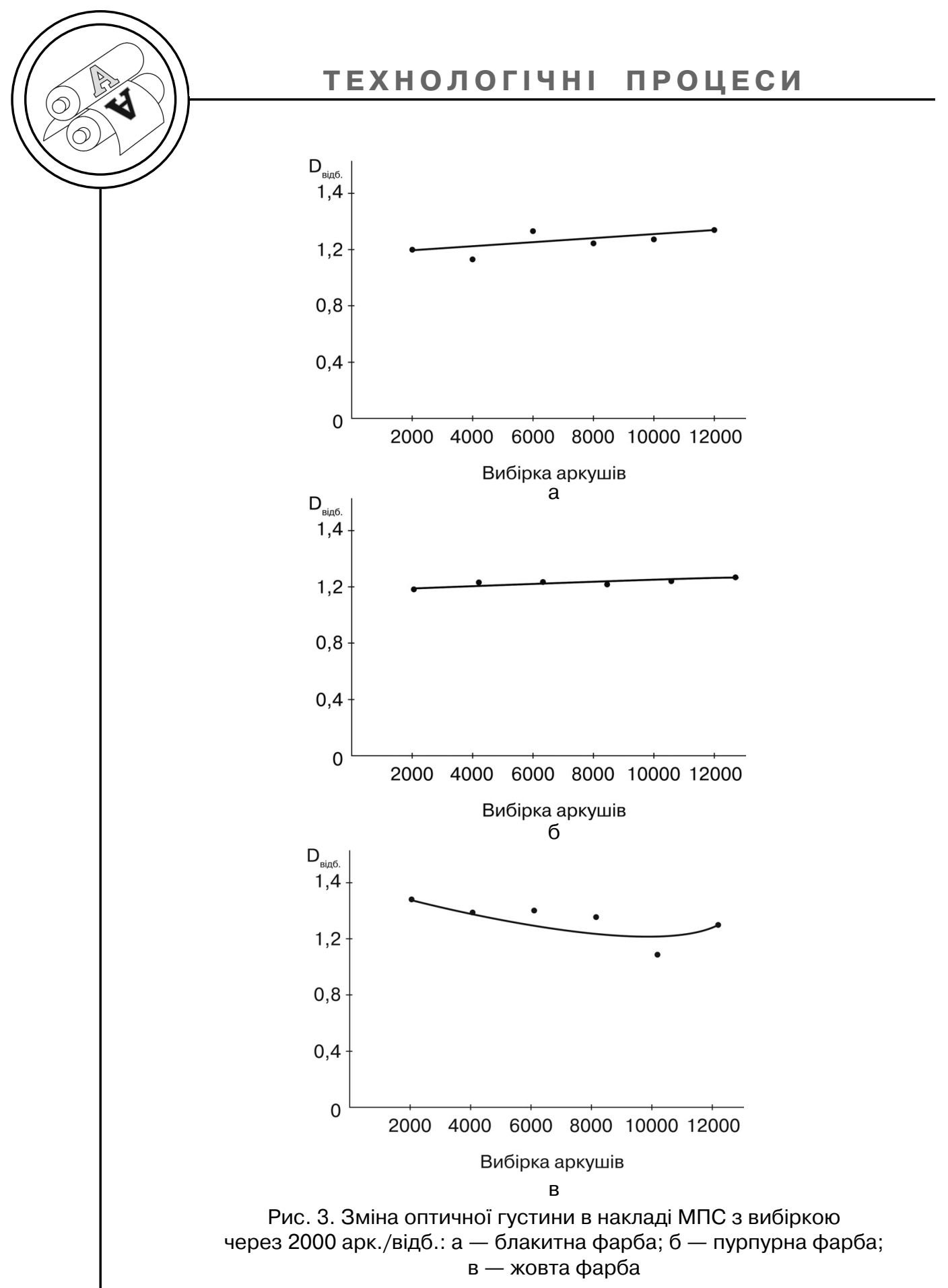

них міжмолекулярних вібрацій у воді. Це призводить до послаблення міжмолекулярних зв'язків і, як основний результат, до зниження поверхневого натягу. В результаті при роботі з такою водою у складі ЗР зникає по- треба у використанні ізопропилового спирту, т. я. поверхневий натяг ЗР знаходиться на оптимальному рівні, який забезпечує спирт, а відповідно, можна друкувати з тією ж якістю растрова крапка стає більш 


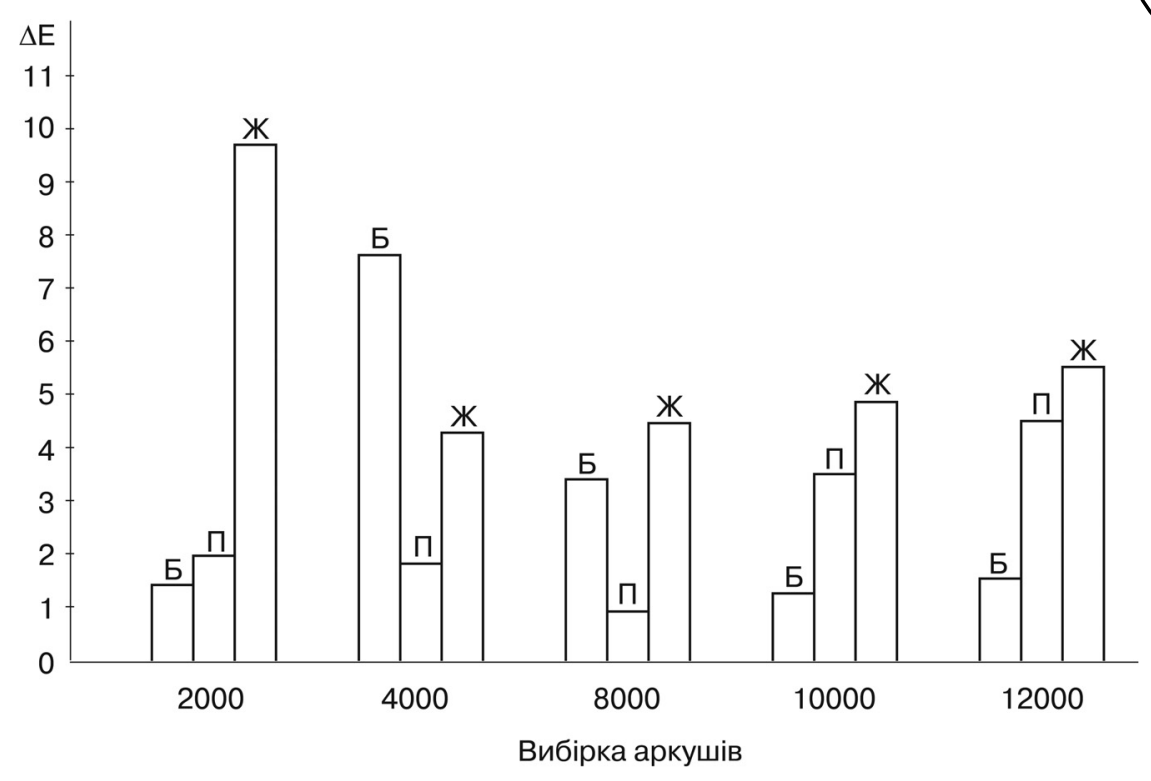

Рис. 4. Колірні відмінності тріадних фарб

чіткою, плашки більш насиченими, кольори більш яскравими.

Ефект молекулярних вібрацій призводить і до інших результатів. Потужні магнітні поля суттєво уповільнюють процес кристалізації солей, і мікрофлора в ній також виникає

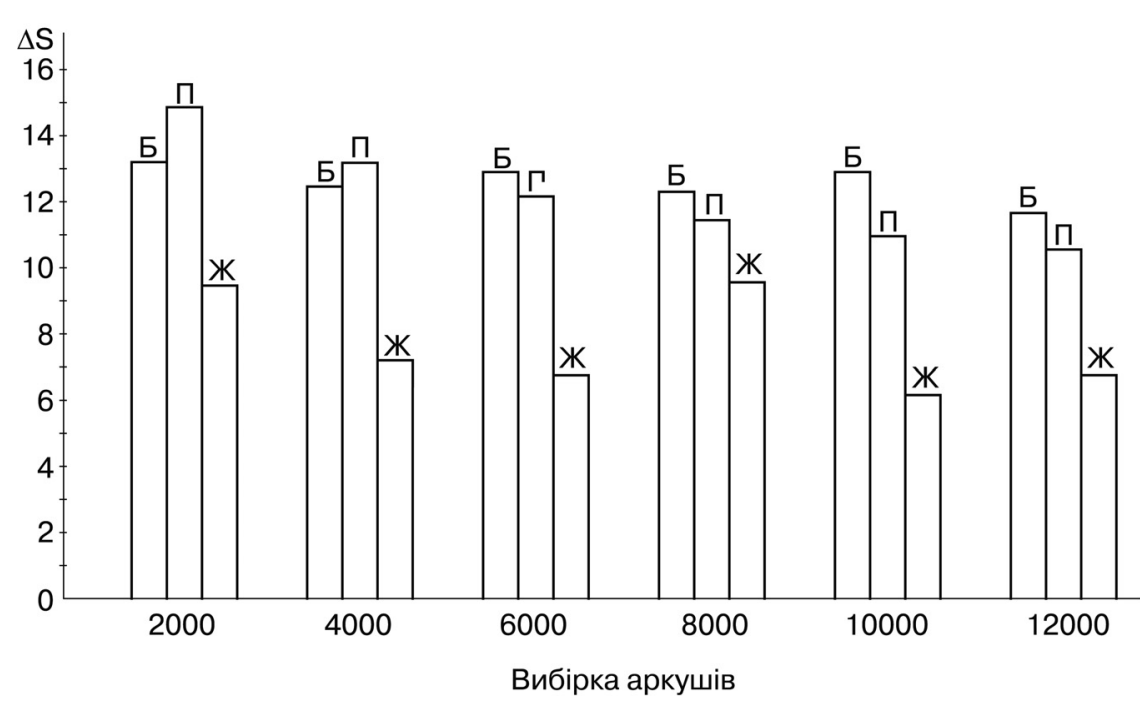

Рис. 5. Розтискування тріадних фарб повільніше. Таким чином, 3Р більш довго залишається чистим [8].

Враховуючи обрану вище автоматизовану систему контролю ЗР в процесі друку, розроблено алгоритм підготовки ЗР із застосуванням даної системи (рис. 6). 


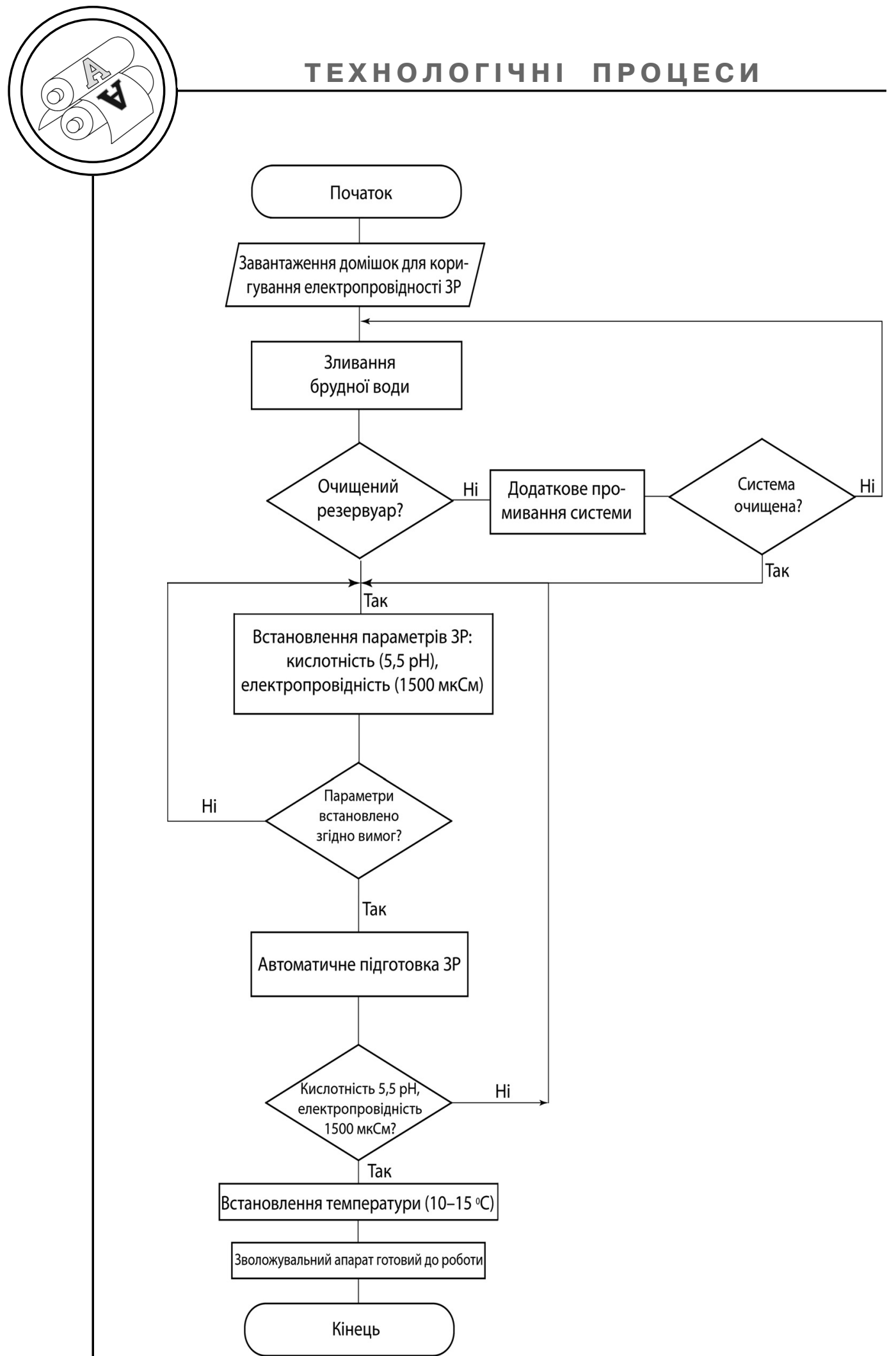

Рис. 6. Алгоритм підготовки ЗР до друку 


\section{Висновки}

Неідентичність відбитків ПМС, як правило, спричиняється порушенням балансу «фарба-ЗР», температурного режиму, складом та фізикохімічними особливостями ЗР, фарби і, як наслідок, зміною фізико-хімічного стану друкарської форми.

Спричинити порушення зволоження форм і призвести до браку продукції може також зміна атмосферних умов цеху та зміна умов циркуляції повітря.

Встановлення пристроїв Optimizer на друкарській ділянці дозволить вирішити проблеми якості друку, суттєво спростить роботу друкарської машини і дозволить:

- автоматично встановлювати і підтримувати на незмінному рівні значення $\mathrm{pH} 3 \mathrm{P}$;

- автоматично підтримувати на заданому рівні жорсткість ЗР (вимірювану за величиною його електропровідності) ;

- підтримувати незмінним без буферних домішок та ізопропилового спирту поверхневий натяг 3Р;
- значно скоротити кількість вапняних відкладень при використанні жорсткої води;

- вирішити ряд екологічних проблем, пов'язаних з впливом випаровування спирту та інших домішок у ЗР;

- отримувати стабільно високу якість друку;

- захистити металеві поверхні друкарської машини від хімічного впливу [8].

Отже, стабільне й ефективне виробництво не тільки дозволяє 3 максимальною якістю виконувати роботи найвищої складності, але й має значний потенціал для розвитку. Постійно розширюючи виробництво, удосконалюючи технології, впроваджуючи найсучасніші методи друку й захисту продукції, що базуються на відтворенні складних графічних елементів, використанні особливих матеріалів і фарб, застосуванні голографічних захисних елементів, методах персоніфікації та наскрізної нумерації тощо ПМС - а це, в свою чергу потребує виняткового рівня організації виробництва, забезпечення надійного обліку, зберігання й транспортування продукції.

1. Величко О. М. Видавничо-поліграфічна справа. Практикум 3 проектування і розрахунку технологічних і виробничих процесів : навч. посіб. / О. М. Величко. - Київ : Видавничо-поліграфічний центр «Київський університет», 2009. - 520 с. 2. В. М. Скиба. Параметри зволоження у сучасних офсетних друкарських комплексах / В. М. Скиба, Р. М. Барчук, Т. Г. Осипова, О. М. Величко // Наукові записки. - 2011. - № 4(37). С. 278-284. 3. Поліграфічний комбінат «Україна» [Електронний ресурс]. Режим доступу : www.pk-ukraina.gov.ua. 4. Технические требования к изготовлению бланков ценных бумаг [Електронний ресурс]. - Режим доступу : www.economedu.ru. 5. Стефанов С. Губит офсет не краска, губит офсет вода [Електронний ресурс] / С. Стефанов // КомпьюАрт. - 2003. № 1. - Режим доступу : www.compuart.ru. 6. Технология цветной печати Управление процессами производства пробных отпечатков и печатных форм методом полутонового цветоделения. - Часть 2: Офсетные литографические процессы [Электронный ресурс] / Международный 


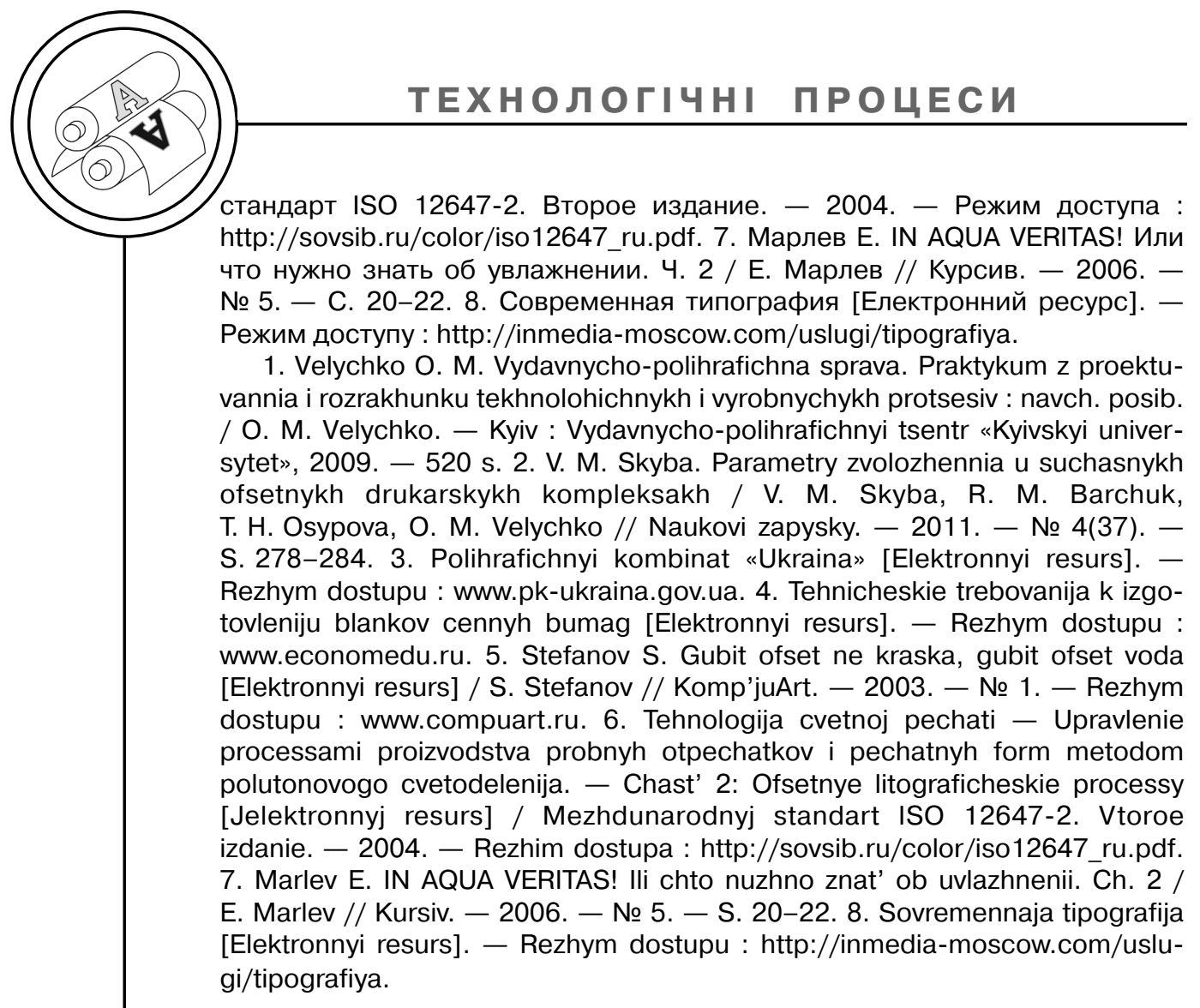

Рецензент - О. М. Величко, д.т.Н., професор, НТУУ «КП।»

Надійшла до редакції 28.09.13 